\title{
Biological active compounds from native food sources for fermented dairy products
}

\section{Mihaela Adriana Tița ${ }^{1}$, Cristina Popovici², Loreta Tamošaitiené ${ }^{3}$, Vijole Bradauskiene ${ }^{3,4}$}

\author{
1 - Lucian Blaga University of Sibiu, Sibiu, Romania \\ 2 - Technical University of Moldova, Chișinău, Republic of Moldova \\ 3 - Klaipeda State University of Applied Sciences, Klaipeda, Lithuania \\ 4 - Kaunas University of Technologies, Food Institute, Kaunas, Lithuania
}

Keywords:

Dairy

Biocompounds

Honey

Walnuts

Sea buckthorn

\section{Article history:}

Received 30.05.2019

Received in revised

form 28.09.2019

Accepted 30.03.2020

\section{Corresponding}

author:

Mihaela Adriana

Tița

E-mail:

mihaela.tita@

ulbsibiu.ro

DOI: $10.24263 / 2304-$

974X-2020-9-1-4

\section{Abstract}

Introduction. The present research aims to identify and quantify valuable compounds from native products such as honey, walnut and sea buckthorn in order to produce fermented product from cow's milk.

Materials and methods. Honey bees of native production polyphora from the Drăgășani area (Romania) were used, and for the identification and quantification of the volatile compounds a GC-MS system was used. Qualitative and quantitative analyzes of the polyphenols were performed using the Agilent 1200 HPLC system consisting of a photodiode array (PDA) detector and an electrospray ionization mass detector.

Results and discussion. In poliflora honey bees, phenolic acids reach $79.284 \mathrm{mg} / 100 \mathrm{~g}$ sample, isoprenoids reach 127.449 $\mathrm{mg} / 100 \mathrm{~g}$ sample, and flavonoids at $168.475 \mathrm{mg} / 100 \mathrm{~g}$ sample, and the results obtained by chromatographic analysis of honey. Bees have been found in this product a wide range of aroma compounds, namely: terpenic compounds, higher alcohols, aldehydes and ketones, esters, so that the aldehydes reach values of $7.889 \mathrm{mg} / 100 \mathrm{~g}$, ketones at $2.337 \mathrm{mg} / 100 \mathrm{~g}$, alcohols higher ones accumulate at amounts of $3.212 \mathrm{mg} / 100 \mathrm{~g}$, and the esters reach values of $8.993 \mathrm{mg} / 100 \mathrm{~g}$. Following the chromatograms obtained, the content of polyphenols in the walnut kernel was established at an amount of $786.553 \mathrm{mgGAE} / 100 \mathrm{~g}$, and for the berries the content in polyphenols was $343.229 \mathrm{mgGAE} / 100 \mathrm{~g}$. Also the highest concentration significant of tocopherols is found in the form of alpha tocopherol, with $33.245 \mathrm{mg} / 100 \mathrm{~g}$, followed by beta tocopherol with an amount of $12.723 \mathrm{mg} / 100$ $\mathrm{g}$ of oil. Values lower than $4.553 \mathrm{mg} / 100 \mathrm{~g}$ and $1.286 \mathrm{mg} / 100 \mathrm{~g}$ respectively are visible in the case of the tocopherol gamma and the tocopherol delta.

Conclusions. The compounds identified and quantified from the three indigenous products such as polyflora honey, walnut and sea buckthorn will lead to the achievement of a harmonious aromatic profile and with certain taste qualities of the new fermented dairy product. 


\section{Introduction}

The actual task is to analyze new perspectives and key areas for future research in the development of high-quality innovative dairy products as a function of valuable compounds from native food products and some new processing techniques. Previous studies [16-18] have shown that bee honey, walnuts and sea buckthorn have a number of positive effects in human nutrition and health, with beneficial action especially in the area of the nervous and vascular system, infectious diseases exerting a pronounced antibacterial action.

The current research has been done is to identify and quantify valuable compounds from honey, walnuts and sea buckthorn in order to produce an innovative fermented product from cow's milk.

\section{Analysies of valuable compounds from native products used in obtaining innovative dairy products}

\subsection{Bee honey: characteristics and valuable components}

Bee honey is a food naturally derived from the processing of floral nectar by bees [32]. It is sweet, so it contains many sugars, aromatic, of different consistencies, with a variable color palette, specific to its composition $[8,10]$. The color palette starts from colorless, yellow, reddish, orange and can reach black $[1,2]$.

Honey is the result of the activity of the bees that collect the nectar with the help of the horn with which they are endowed, keep it in the goose, mix it with saliva and then a transfer to the bees left in the hive in a sugary form, which continues the processing until it reaches the known form $[16,33]$.

2.1.1. Bee honey and its sensory characterization. The appearance of honey and the color can be appreciated according to the degree of transparency examined in the direct sunlight $[3,7]$.

The taste and smell are appreciated by noting the intensity of the aroma and the sweet taste, or of the possible secondary shades:sour, bitter, fad, etc. conferred including polyphenols (Table 1) $[4,5]$.

Sensory characteristics

Table 1

\begin{tabular}{|c|l|l|}
\hline No & Characteristics & \multicolumn{1}{c|}{ Conditions of admissibility } \\
\hline 1 & Color & From colorless, bright yellow, to orange \\
\hline 2 & Taste & Sweet, pleasant, \\
\hline 3 & Appearance & Semifluid, viscous or crystallized \\
\hline 4 & Flavor & Floral, characteristic of the type of honey \\
\hline
\end{tabular}

2.1.2. Beehoneyandits chemical composition. The chemical composition of honey bees depends to a large extent on the climatic factors and the vegetal nature of the collection area, the mode of exploitation of the product by the beekeepers, its properties being in direct correlation with them [6-10]. 
Bee honey contains protein substances, a number of microelements and vitamins (C, B1, B6, B2), small quantity organic acids (citric, lactic, malic, oxalic, succinic), dextrins, odorants and dyes, with clinical effects. Relevant, but also presents a microbiological load worth studying [11-15].

All honey is acidic and has a pH value generally between 3.5 and 5.5, due to the presence of organic acids that contribute to honey aroma and stability to microorganisms [11]. In honey, the main acid is gluconic acid, which is found together with the respective glucono-lactone in a variable equilibrium (Table 2) [9].

Physico-chemical and microscopic characteristics

Table 2

\begin{tabular}{|c|l|c|c|c|}
\hline No & \multicolumn{1}{|c|}{ Parameter } & Acacia honey & $\begin{array}{c}\text { Forest } \\
\text { honey }\end{array}$ & $\begin{array}{c}\text { Other } \\
\text { assortments }\end{array}$ \\
\hline 1 & Water,\% max & 20 & 20 & 20 \\
\hline 2 & Acidity, ml NaOH 1N/ 100g, max & 4 & 5 & 4 \\
\hline 3 & $\begin{array}{l}\text { Reducing sugar, expressed in } \\
\text { invert sugar,\% min }\end{array}$ & 70 & 60 & 70 \\
\hline 4 & Amylase index, min & 6,5 & 13,9 & 10,9 \\
\hline 5 & Ash,\% max & 0,5 & 1,0 & 0,5 \\
\hline 6 & $\begin{array}{l}\text { Hydroxymethylfurfural, mg/100g } \\
\text { max }\end{array}$ & 1,5 & 1,5 & 1,5 \\
\hline 7 & $\begin{array}{l}\text { Colorimetric index, mm, max (on } \\
\text { the Pfund scale) }\end{array}$ & 12 & 65 & - \\
\hline 8 & Water insoluble substances, max & 0,1 & 0,2 & 0,1 \\
\hline 9 & $\begin{array}{l}\text { Lightly hydrolyzable sugar, } \\
\text { expressed as sucrose,\% max }\end{array}$ & 5 & 10 & 5 \\
\hline
\end{tabular}

2.1.3. Microbiological indicators of honey. Microbiological indicators of honey are presented in Table 3[12].

Microbiological indicators of honey

Table 3

\begin{tabular}{|c|l|c|c|c|c|}
\hline No & \multicolumn{1}{|c|}{ Specification } & NTM/g & $\begin{array}{c}\text { Number of } \\
\text { yeasts / g }\end{array}$ & Molds & $\begin{array}{c}\text { Pathogenic } \\
\text { microflora }\end{array}$ \\
\hline 1 & Normal honey & $<300$ & $2-3$ & absent & Absence \\
\hline 2 & $\begin{array}{l}\text { Honey with limited } \\
\text { conservabilitate }\end{array}$ & $<300$ & $10-10^{2}$ & absent & Absence \\
\hline 3 & $\begin{array}{l}\text { Honey coming out } \\
\text { of consumption }\end{array}$ & $>300$ & $10^{4}$ & present & Present \\
\hline
\end{tabular}

In order to detect forgeries, the physico-chemical control of honey is done by several methods: determination of acidity index, determination of sucrose (based on the identification of sucrose from honey forged with sugar syrup by reaction with silver nitrate), determination of the addition of flour or starch (based on the color reaction of starch with iodine), identification of honey nitrites $[12,13]$. 


\subsection{Walnuts: characteristics and valuable components}

Walnuts (Juglansregia L.) belong to the family Juglandaceae. The native region of which they come is Central Asia, the western Himalayan chain, the region of Kyrgyzstan [19]. They arrived in Europe before the Roman era, and later spread to America and North Africa [21]. Walnuts and hazelnuts (Corylusavellana L.) make up about $60 \%$ of walnut production in Europe [20].

The results of clinical and epidemiological studies clearly indicate that regular consumption of nuts reduces the risk of cardiovascular disease, diabetes, cancer and inflammatory diseases [21]. According to many authors, these properties result from the chemical composition of walnuts. First, they are a rich source of fat (up to $70 \%$ dry mass), including unsaturated fatty acids, as well as phytochemicals such as phenols, tocopherols and sterols $[19,20]$. In addition, walnuts contain polyunsaturated fatty acids (PUFAs) that lower LDL cholesterol and increase HDL cholesterol [22]. Moreover, nuts contain dietary fiber and essential micronutrients [23].

Nuts are also a rich source of complete proteins, which are abundant in exogenous amino acids, as well as minerals, including potassium and magnesium [24]. In walnut oil, there are a number of active phytochemicals that consist mainly of polyphenols [26]. In terms of polyphenol content, nuts dominate among all nuts; their average polyphenol content is about $1591.5 \mathrm{mg} / 100 \mathrm{~g}$, and in peanuts it varies widely up to $900 \mathrm{mg} / 100 \mathrm{~g}$ [21-23]. Of all the polyphenols identified in walnuts, elagitannins are the most numerous group, followed by phenolic acids, flavanols and dihydroclacones [24-26].

\subsection{Sea buckthorn (Hippophae rhamnoides L.): characteristics and valuable components}

The sea buckthorn (Hippophaerhamnoides L.) presents a series of properties beneficial to the human body, through its rich content in minerals and vitamins. It presents a series of bactericidal and bacteriostatic effects, being rich in antioxidants that have the effect of neutralizing free radicals, is implicated by its composition in the elimination of toxins from the body [27].

Sea buckthorn contains over 200 bioactive components and volatile compounds, many vitamins (including A, P, C, B1, F, B2, E, K), carotenoids, tocopherols, sterols, flavonoids, phenolic compounds, lipids, ascorbic acid, citric acid and more than 15 microelements (including Fe, Mn, B, Al, K, F, Ti) [27]

Catenin reduces liver injury by antioxidant activity [28]. The sea buckthorn pulp is rich in carotenoids, tocopherols, sterols, lipids, ascorbic acid, flavonoids, triterpenes, etc. These compounds have biological activities and therapeutic properties such as antioxidants, antitumor and immunomodulators [29, 30]. In addition to medicinal use, the pulp is processed into different products, such as juice and jam [28].

Studies have shown the efficiency of dog consumption in the recovery of cancer patients, those with epidermal problems, being an optimal raw material including in the cosmetic industry [31]. 


\section{Materials and methods}

\subsection{Experimental samples}

Polyflora honey, walnut kernel and sea buckthorn berries are valued as a source of natural compounds with antioxidant properties and pleasant sensory profile. In this study honey of polyflorous bees of local production in the Drăgășani area(Romania), walnut kernel arising from Station for Horticulture Research and Development (SCDP)(Romania), and sea buckthborn from Agricultural Cooperative from Biocătina (CAB) (Romania) were used.

\subsection{Determination of phenolic compounds in honey}

For quantification and determination of phenolic compounds, $100 \mathrm{~g}$ of honey were dissolved in $500 \mathrm{ml}$ of acidified water $(\mathrm{pH}=2, \mathrm{HCl})$ [4]. The solution was then filtered with cotton to remove the solid particles. The obtained filtrate was passed through an Amberlite XAD-2 column, which has the ability to selectively retain phenolic compounds. To remove sugars and other polar compounds, a wash was carried out with the passage of acidified water to $\mathrm{pH}=2$. Subsequently, the phenolic fraction was eluted with methanol and the extract was concentrated under reduced pressure at $40{ }^{\circ} \mathrm{C}$. The final residue was then redissolved in $5 \mathrm{ml}$ of distilled water and subjected to liquid/liquid extraction, using diethyl ether as the extraction solvent. The extracts were concentrated under reduced pressure, and the residue was dissolved in methanol.

The chromatographic system consisted of a quaternary pump, an automatic sampler maintained at $5{ }^{\circ} \mathrm{C}$, a degasser, a photodiode detector and an automatic compartment for thermostatic columns. Chromatographic separation was performed with a C18 column of particles having a size of $1.8 \mu \mathrm{m}$ and maintained at $30{ }^{\circ} \mathrm{C}$. The mobile phase was composed of $0.1 \%$ formic acid diluted in water and $0.1 \%$ formic acid dissolved in acetonitrile, previously degassed and filtered using a nylon membrane filter with a porosity of $0.22 \mu \mathrm{m}$. The injection volume was $3 \mu \mathrm{l}$. Spectral data for all peaks were detected in the range 190$600 \mathrm{~nm}$.

Each sample was filtered through a $0.2 \mu \mathrm{m}$ nylon membrane (Whatman). The mass analysis was performed on a Varian 240 mass spectrometer in negative mode, equipped with an ESI electro-spray ionization source: spray voltage, $5 \mathrm{kV}$; capillary voltage, $-20 \mathrm{~V}$; capillary tube voltage, $-65 \mathrm{~V}$; capillary temperature, $325{ }^{\circ} \mathrm{C}$; gas flow and auxiliary gases $(\mathrm{N} 2)$, respectively 50 and 10 (arbitrary units). The mass spectra were obtained in the mass range $100-1000 \mathrm{mz}$.

The collision energy used in the MSn experiments was 35 (arbitrary units). Data acquisition was performed using Xcalibur ${ }^{\circledR}$ software (Thermo Scientific, CA, USA). The quantification was performed with calibration curves of the standard substances for caffeic acid quercetin, caempferol, chrysine and pinocembrine. In the absence of standards the compounds were expressed by equivalents of the more structurally similar phenolic compound (method adopted and adapted after Silva Caveiro [31].

\subsection{Determination of volatile compounds in honey}

A GC-MS system was used to identify and quantify volatile compounds: GC-MS Varian 240 with column C18, helium carrier gas, the temperature being set upwards by $3{ }^{\circ} \mathrm{C} / \mathrm{min}$ up to $170{ }^{\circ} \mathrm{C}$, later with $25^{\circ} \mathrm{C} / \mathrm{min}$ up to $290{ }^{\circ} \mathrm{C} / \mathrm{min}$. The volatile compounds were identified by comparing the spectra obtained with those from the laboratory library $[6$, 25]. 


\subsection{Determination of phenolic compounds in walnuts and sea buckthorn fruit}

Qualitative and quantitative analyzes of the polyphenols were performed using the HPLC Agilent 1200 system consisting of a photodiode array (PDA) detector and an electrospray ionization mass detector. The polyphenolic compounds were separated on a $\mathrm{C} 18$ column using a linear gradient of 8 minutes. Solvents were used: solvent B containing $40 \%$ acetonitrile and $0.1 \%$ formic acid and solvent A: ultrapure water containing $0.1 \%$ formic acid at a flow rate of $0.30 \mathrm{~mL} / \mathrm{min}$. The injection volume of the samples was $5 \mu \mathrm{L}$. The readings of the polyphenolic compounds were performed at the following wavelengths: hydroxycamines at $320 \mathrm{~nm}$ and the ellagic tannins at $240 \mathrm{~nm}$. Gallic acid was used as an equivalent [20,23].

\subsection{Determination of tocopherol compounds in walnuts and sea buckthorn fruit}

To analyze the content of tocopherols, the oil extracted from nuts and sea buckthorn was used using the Soxhlet method. The tocopherol content $(\alpha, \beta, \gamma, \delta)$ was measured by high performance liquid chromatography (HPLC) according to the method adapted by Pycia et al. The chromatography system consisted of an Agilent 1200 HPLC chromatograph, a C18 column. As a mobile phase, methanol with a flow rate of $0.8 \mathrm{~mL} / \mathrm{min}$ and a Shimadzu fluorescence detector with the extinction wavelength set at $290 \mathrm{~nm}$ and the emission wavelength at $330 \mathrm{~nm}$ were used. The injection volume of a measured sample was $20 \mu \mathrm{L}$. Tocopherols were quantified using standard curves calculated by linear regression analysis [19].

\section{Results and discussions}

\subsection{Identification and quantification of phenolic compounds in honey}

In order to approach as accurately as possible, the phenolic compounds in the honey of the bees subjected to the study, they were summed according to their chemical classification, namely: phenolic acids, flavonoids, isoprenoids (Figure 1).

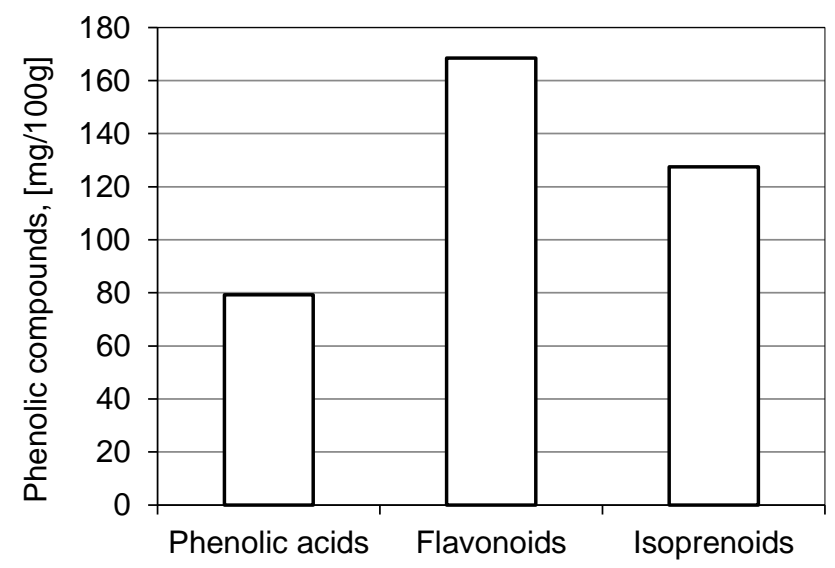

Figure 1. Sum of the phenolic compounds identified and quantified in the honey of poliflorine bees from Drăgășani 
The amount of these compounds varies in the sample taken from $79.284 \mathrm{mg} / 100 \mathrm{~g}$ to $168.475 \mathrm{mg} / 100 \mathrm{~g}$ (Figure 1). Phenolic acids reach $79.284 \mathrm{mg} / 100 \mathrm{~g}$ sample, isoprenoids reach $127.449 \mathrm{mg} / 100 \mathrm{~g}$, and flavonoids to $168.475 \mathrm{mg} / 100 \mathrm{~g}$ sample.

\subsection{Identification and quantification of volatile compounds in honey}

The presence of volatile compounds in honey can provide information on its botanical origin, allowing it to verify whether it was produced by bees from the nectar of flowers or exudates secreted by plants or insects [3, 6].Over 500 volatile compounds have been identified in honey as complex mixtures of different classes of compounds such as terpenes, isoprenoids, phenolic compounds, benzene derivatives, alcohols, ketones, aldehydes, esters, fatty acids, linear hydrocarbons and cyclical [33]. As a result of the results obtained by the chromatographic analysis of honey bee, it was found that in this product there is a wide range of aroma compounds, namely: terpenic compounds, higher alcohols, aldehydes and ketones, esters (Figure 2).

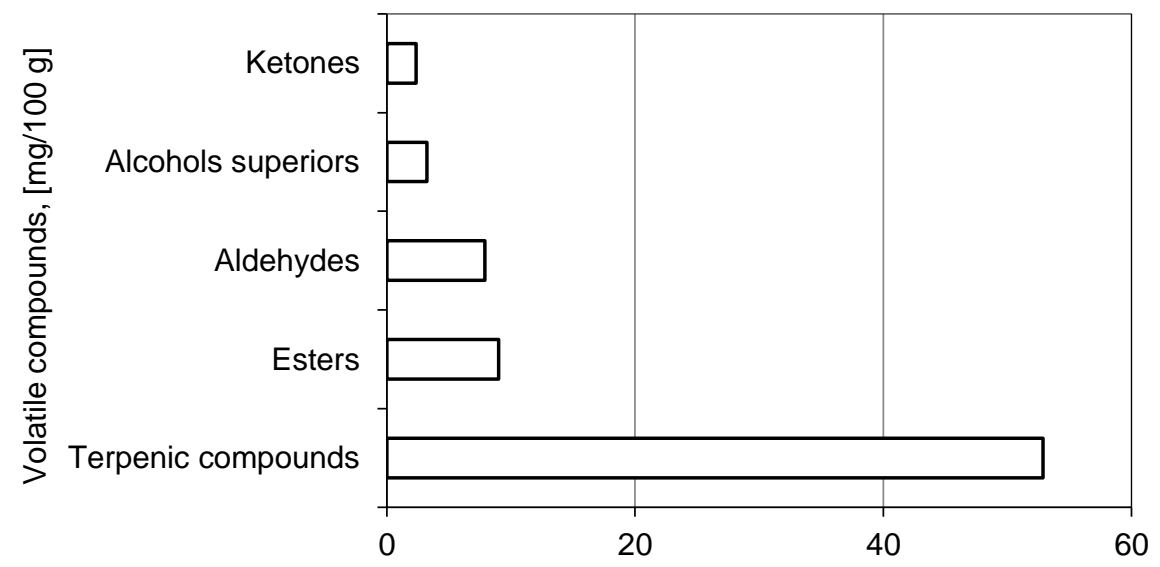

Figure 2. Sum of the volatile compounds identified and quantified in the honey of polyflorous bees from Drăgășani

We observe the determined quantities, noting especially the terpenic ones (Figure 2). From the results obtained the hotrienol is identified in remarkable amounts, the identified values being $47.335 \mathrm{mg} / 100 \mathrm{~g}$, and the sum of the terpenic compounds reaches 52.867 $\mathrm{mg} / 100 \mathrm{~g}$. Aldehydes reach values of $7.889 \mathrm{mg} / 100 \mathrm{~g}$ and ketones reach $2.337 \mathrm{mg} / 100 \mathrm{~g}$. Higher alcohols accumulate at $3.212 \mathrm{mg} / 100 \mathrm{~g}$, and esters reach $8.993 \mathrm{mg} / 100 \mathrm{~g}$.

\subsection{Identification and quantification of phenolic compounds in walnuts and fruits of sea buckthorn}

Polyphenols are chemical compounds with multiple beneficial effects on the human body, generally acting as powerful antioxidant elements [20]. They are found in many fruits and vegetables, offering protection against free radicals [29, 30]. During the study it was determined the total polyphenol content in walnuts and sea buckthorn samples (Figure 3). 


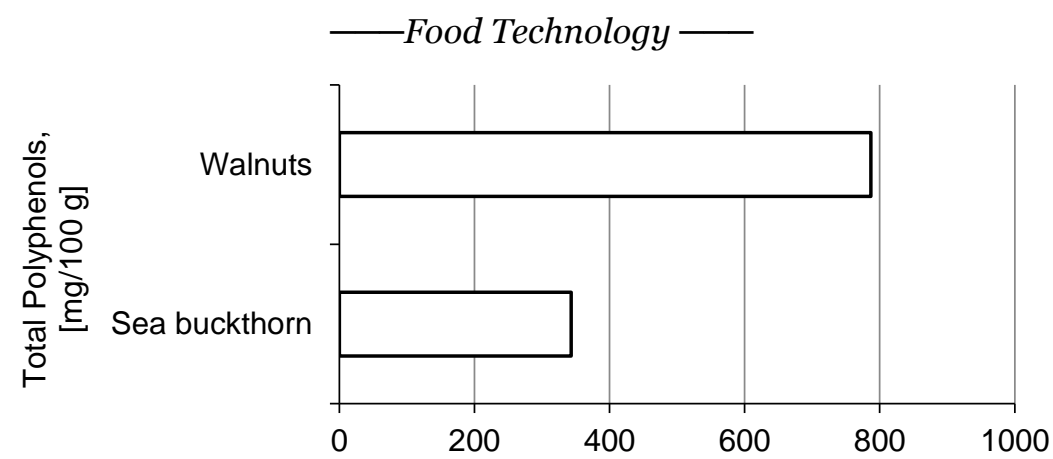

Figure 3. Total polyphenol concentration identified in walnut kernel and sea buckthorn expressed in gallic acid equivalent

Following the chromatograms obtained, the content of polyphenols in the walnut kernel was established, which is at an amount of $786.553 \mathrm{mgGAE} / 100 \mathrm{~g}$ according to Figure 3 . For the berries the content in polyphenols is $343.229 \mathrm{mgGAE} / 100 \mathrm{~g}$.

\subsection{Identification and quantification of tocopherols in walnuts and fruits of sea buckthorn}

Tocopherols or vitamin $\mathrm{E}$ is beneficial to the human body by its pronounced antioxidant character which leads to neutralization and elimination of free radicals [19]. The most active tocopherol is alpha, but it is found in walnut and buckwheat oil and as tocopherol beta, gamma or delta, or tocotrienol [24, 29]. During this study there were identified and determined several tocopherols: alpha, beta-, gamma and delta in the oil extracted from walnut (Figure 4).

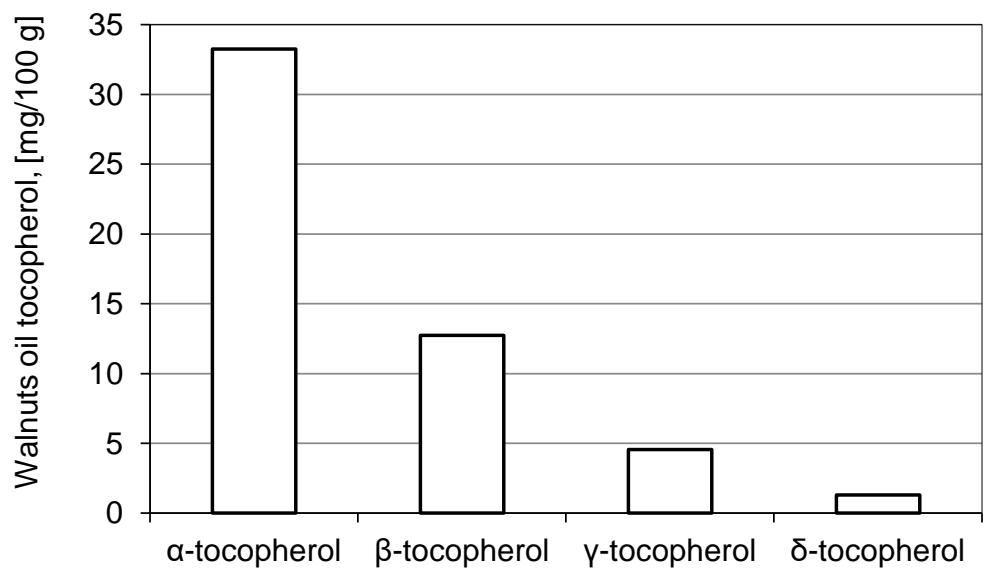

Figure 4. The concentration of tocopherols identified and quantified in the oil extracted from walnut 
The most significant concentration of tocopherols (Figure 4) is found as alpha tocopherol, with $33.245 \mathrm{mg} / 100 \mathrm{~g}$, followed by beta tocopherol with an amount of 12.723 $\mathrm{mg} / 100 \mathrm{~g}$ oil. Values lower than $4.553 \mathrm{mg} / 100 \mathrm{~g}$ and $1.286 \mathrm{mg} / 100 \mathrm{~g}$ respectively are visible in the case of the tocopherol gamma and the tocopherol delta.

Experimental results obtained regarding the tocopherols concentration in the oil extracted from the sea buckthorn are presented in Figure 5.

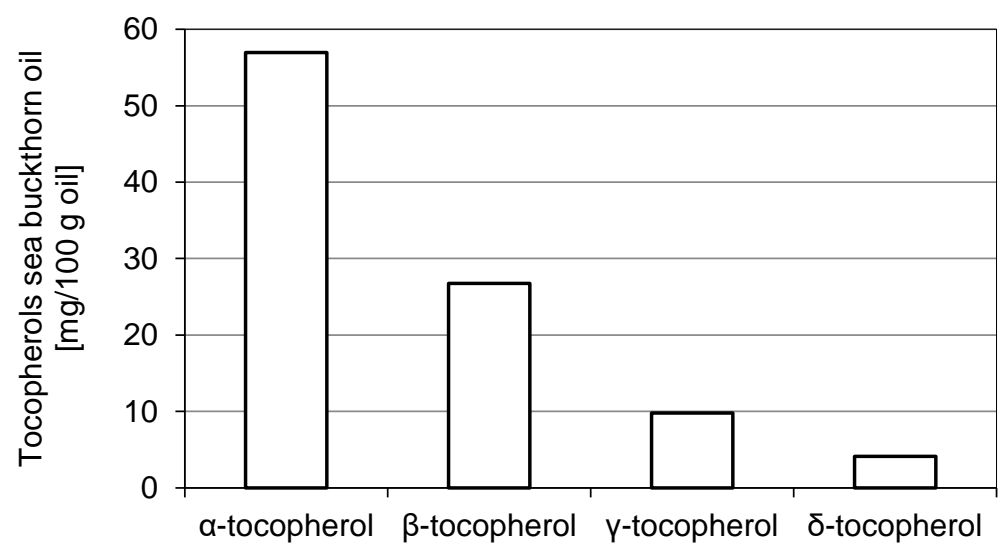

Figure 5. The concentration of tocopherols identified and quantified in the oil extracted from the fruit of sea buckthorn

A maximum concentration of alpha tocopherolsin the amount of $56.973 \mathrm{mg} / 100 \mathrm{~g}$ is observed, followed by $26.771 \mathrm{mg} / 100 \mathrm{~g}$ beta tocopherols (Figure 5). Lower values of 9.774 $\mathrm{mg} / 100 \mathrm{~g}$ were identified in the case of tocopherol gamma and of $4.123 \mathrm{mg} / 100 \mathrm{~g}$ in the case of the tocopherol delta. Compared with the values identified in walnut oil, the values found in sea buckthorn oil are more significant.

\section{Conclusions}

Bee honey contains significant values of phenolic compounds, compounds that confer antioxidant qualities associated with nutritional ones.

The volatile compounds identified and quantified in honey bees lead to the achievement of a harmonious aromatic profile and with certain gustatory qualities, the share having terpenic compounds and esters.

The tocopherols identified and quantified in the oil extracted from the walnut core have significant values especially in the form of alpha tocopherols. Compared with the values identified in sea buckthorn oil, they are lower on average by $45 \%$.

The ratio of alpha tocopherols to beta, gamma and delta tocopherols is on average $7: 3$, slight oscillations being visible in those identified and quantified in sea buckthorn oil.

The results of the present study suggest that bee honey, walnuts and sea buckthorn berries can be used as a valubele source of natural antioxidants and volatile compounds for obtaining innovative dairy milk products. 


\section{References}

1. Bogdanov S., Jurendic T., Sieber R., Gallmann P. (2008), Honey for Nutrition and Health: A Review, Journal of the American College of Nutrition, 27(6), pp. 677-89.

2. Chakir A., Romane A., Barbagianni N., Bartoli D., Ferrazzi P. (2011), Major and trace elements in different types of Moroccan honeys, Australian Journal of Basic and Applied Sciences, 5, pp. 223-231.

3. Piana M. L., Oddo L. P., Bentabol A., Bruneau E., Bogdanov S., Declerck C. G. (2004), Sensory analysis applied to honey: state of the art, Apidologie, 35(26), p. 37.

4. Pyrzynska K., Biesaga M. (2009), Analysis of phenolic acids and flavonoids in honey. TrACTrends in Analytical Chemistry, 28(7), pp. 893-902.

5. Simuth J. (2001), Some properties of the main protein of honeybee (ApisMellifera) Royal Jelly, Apidology, 32, pp. 69-80.

6. Cuevas-Glory L.F., Pino J.A., Santiago L.S., Sauri-Duch E. (2007), A review of volatile analytical methods for determining the botanical origin of honey, Food Chemistry, 103(3), pp. 1032-1043.

7. De-Melo A.A.M., Almeida-Muradian L.B., Sancho M.T., Pascual-Maté A. (2018), Composition and properties of Apismelliferahoney: A review; Journal of apicultural research, 57, pp.5-37.

8. Escuredo O., Míguez M., Fernández-González M., Seijo M. C. (2013), Nutritional value and antioxidant activity of honeys produced in a European Atlantic area, Food Chemistry, 138(2-3), pp. 851-856.

9. Estevinho L.M., Feás X., Seijas J.A., Vásquez-Tato M. P. (2012), Organic honey from TrásOs-Montes region (Portugal): Chemical, palynological, microbiological and bioactive compounds characterization, Food and Chemical Toxicology, 50, pp. 258264.

10. Soares S., Amaral J.S., Oliveira M.B.P.P., Mafra I. (2017), A Comprehensive Review on the Main Honey Authentication Issues: production and Origin comprehensive, Reviews in Food Science and Food Safety, 16, pp.1072-1100.

11. Feás X., Iglesias A., Rodrigues S., Estevinho L. M. (2013), Effect of Erica sp. Honey against Microorganisms of Clinical Importance: Study of the Factors Underlying this Biological Activity, Molecules, 18, pp. 4233-4246.

12. Finola M. S., Lasagno M. C., Marioli J. M. (2007), Microbiological and chemical characterization of honeys from central Argentina, Food Chemistry, 100, pp. 16491653.

13. Iurlina M. O., Fritz R. (2005), Characterization of microorganisms in Argentinean honeys from different sources, International Journal of Food Microbiology, 105, pp. 297-304.

14. Pavelková A., Kačániová M., Čuboň J., Švecová Z., Kňazovická V., Felsöciová S. (2013), Physicochemical and microbiological quality oh honey from Liptov Region. Jornal of Microbiological, Biotechnology and Food Sciences, 2, pp. 1185-1193.

15. Sodré G. S., Marchini L. C., Moreti A. C. C., Otsuk I. P., Carvalho C. A. L. (2007), Caracterizaçãofísico-química de amostras de méis de ApismelliferaL. (Hymenoptera: Apidae) do Estado do Ceará, Ciência Rural, 37(4), pp. 1139-1144.

16. Alvarez-Suarez J., Tulipani S., Romandini S., Bertoli E., Battino, M. (2010), Contribution of honey in nutrition and human health: a review, Mediterranean Journal of Nutrition and Metabolism, 3, pp. 15-23.

17. Olaitan P. B., Adeleke O. E., Ola I. O. (2007), Honey: a reservoir for microorganisms and an inhibitory agent for microbes. African Health Sciences, 7, pp. 159. 
18. Pereira P.J.M.F. (2007), Propriedadesantibacterianas do mel. Tese de licenciaturaemCiências da nutrição, Faculdade de ciências da nutrição e alimentação, Universidade do Porto, pp.1-36.

19. Abdallah IB., Tlili N., Martinez-Force E., Preze-Rubio A.G., Perez-Camino M.C., Albouchu A., BoukhchinaS.(2015), Content of carotenoids, tocopherols, sterols, triterpenic and aliphatic alcohols, and volatile compounds in six walnuts (Juglansregia L.) varieties. Food Chemistry, 173, pp. 972-978.

20. Persic M., Mikulic-Petkovsek M., Slatnar A., Solar A., VebericR.(2018), Changes in phenolic profiles of red-colored pellicle walnut and hazelnut kernel during ripening, Food Chemistry, 252, pp. 349-355.

21. Ros E. (2010), Health benefits of nut consumption, Nutrients, 2, pp. 652-682.

22. Ros E., Tapsell L.C., Sabaté J. (2010), Nuts and berries for heart health,Curr. Atheroscler, 12, pp. 397-406.

23. Chang S.K., Alasalvar C., Bolling B.W., Shahidi F. (2016), Nuts and their co-products: The impact of processing (roasting) on phenolics, bioavailability, and health benefitsA comprehensive review, J. Funct. Food, 26, pp. 88-122.

24. Chen C.Y., Blumberg J.B. (2008), Phytochemical composition of nuts, Asia Pac. J. Clin. Nutr., 17, pp. 329-332.

25. Fortini M., Migliorini M., Cherubini C., Cecchi L., Calamai L. (2017), Multiple internal standard normalization for improving HS-SPME-GC-MS quantitation in virgin olive oil volatile organic compounds (VOO-VOCs) profile,Talanta, 165, pp. 641-652.

26. Alasalvar C., Shahidi F. (2008), Tree nuts: Composition, phytochemicals, and health effects, CRC Press, Boca Raton.

27. Socaci S.A., Socaciu C., Tofană M., Rat I., Pintea A. (2013), In-tube extraction and GCMS analysis of volatile components from wild and cultivated sea buckthorn (Hippophae rhamnoides L. ssp. Carpatica) berry varieties and juice. Phytochem Anal, 24, pp. 319.

28. Yang B.R., Markku A., Petri M., Heikki K. (2011), Composition and antioxidative activities of supercritical CO2-extracted oils from seeds and soft parts of northern berries. Food Res Int, 44(7), pp. 2009-2017.

29. Nitin K., Upadhyay M.S., Yogendra K., Asheesh G. (2010), Antioxidant, cytoprotective and antibacterial effects of sea buckthorn (Hippophae rhamnoides L.) leaves, Food Chem Toxicol, 48, pp. 3443.

30. Negi P.S., Chauhan A.S., Sadia G.A., Rohinishree Y.S., Ramteke R.S. (2005), Antioxidant and antibacterial activities of various seabuckthorn (Hippophae rhamnoides L.) seed extracts, Food Chemistry, 92, pp. 119.

31. Silva Caveiro E.M., (2017), Caracterização de méiscomerciaisrotulados com a designação de mel de urze, Dissertaçãoapresentada à Escola Superior Agrária de Bragança para obtenção do Grau de MestreemQualidade e SegurançaAlimentar, pp. 2537.

32. Vyshniak V., Dimitriev O., Litvynchuk S., Dombrovskiy V. (2018), Identification of beeswax and its falsification by the method of infrared spectroscopy, Ukrainian Food Journal, 7(3), pp. 421-433.

33. Aliya M. Sajwani, Sardar A. Farooq, Elsadig A. Eltayeb (2019), Differentiation of Omani Acacia and White Acacia honey by botanical and physicochemical analysis, Ukrainian Journal of Food Science, 7(2), pp. 264-285. 